\title{
SUPERMARKET FLUID MILK PRICING PRACTICES IN THE WESTERN UNITED STATES
}

Hoy F. Carman, Professor

Department of Agricultural and Resource Economics

University of California, One Shields Avenue

Davis, California, 95616

Phone: (530) 752-1525; Fax: (530) 752-5614; email: carman@primal.ucdavis.edu

Richard J. Sexton, Professor

Department of Agricultural and Resource Economics

University of California, One Shields Avenue

Davis, California, 95616

Phone: (530) 752-4428; Fax: (530) 752-5614; email: rich@primal.ucdavis.edu

\begin{abstract}
This study analyzes retail milk pricing by supermarkets and marketing margin behavior for four fluid milk products in nine large metropolitan markets in the Western United States. Three empirical measures provide significant evidence of noncompetitive price behavior in each of the markets. Correlations of retail price changes indicate considerable pricing independence among retailers across cities, while rankings of retail prices by milk product provide significant evidence that prices are not based primarily on costs, as would be true if pricing were competitive. Estimated retail price responses to farm price changes are consistent with monopoly pricing behavior for several of the milk products in several of the markets. (EconLit, L660, L810) Keywords: milk, retail, prices, monopoly, margins.
\end{abstract}




\section{INTRODUCTION}

Retail milk pricing practices by U.S. supermarkets in California and other Western states in the U.S. are controversial. Consumer organizations charge that retail milk prices are "too high" because supermarkets increase retail prices immediately when farm prices increase, or even when a farm price increase is announced, and maintain retail prices when farm prices decrease. They have taken their arguments to the California legislature in a thus far unsuccessful effort to secure legislation that would decrease retail milk prices. During the last 10 years total fluid milk consumption in California has decreased despite an 11 percent increase in total population, and consumption has shifted from whole and reduced fat milk to low fat and skim milk. The story is similar for many other states. The decrease in fluid milk consumption concerns milk producers, who receive higher prices for Class I milk used for fluid consumption, as well as public health officials, who recognize the important role of dairy products in overall nutrition and calcium intake.

The purpose of this study is to analyze retail milk prices in California and neighboring states to determine the effects of retail pricing practices on the level and stability of prices paid by consumers. Monthly data from April 1999 - April 2003 (49 months) for California's four major metropolitan markets and the largest metropolitan markets in five neighboring states are utilized in the investigation. California retail milk prices and marketing margins for whole, two percent, one percent and skim milk products in gallon containers in the four largest metropolitan markets (Sacramento, San Francisco, Los Angeles and San Diego) are described and compared with those in major retail markets in neighboring states (Seattle, Portland, Salt Lake City, Denver and Phoenix). Departures of retail prices from those predicted by the competitive model are identified and described. 
Controversy over milk prices in California has stimulated a number of prior surveys and studies. Consumers Union used surveys of retail milk prices in both the San Francisco Bay and Los Angeles areas to demonstrate that retail milk prices were slow to decrease in response to farm-level reductions in the price of milk (Odabashian, 1997a, 1997b). Carman (1998) examined the adjustment of retail milk prices to farm price changes in three California markets, Sacramento, San Francisco and Los Angeles, using monthly prices for gallon containers of whole milk for the period from January 1985 through March 1997. He concluded that there was a strong direct relationship between farm and retail milk prices for both farm price increases and decreases and that there was no statistical evidence that retailers increased prices more when farm prices increased than they decreased retail prices when farm prices decreased. However, evidence did suggest that retail milk prices increased faster when farm prices increased than they decreased when farm prices decreased. Finally, retail price responses to farm price changes varied by market. Los Angeles area retailers maintained more stable retail prices than retailers in Sacramento and San Francisco by absorbing some of the cost increases and not fully passing on decreases in farm prices. ${ }^{1}$

\section{ANALYTICAL MODELS AND APPROACHES}

California farm level prices for milk are set each month by the California Department of Food and Agriculture using formulas established by state legislation. Farm prices in neighboring states are determined under provisions of applicable Federal milk marketing orders. In a perfectly competitive market, farm-level price changes would be transmitted quickly to the retail market, and retail price differences for milk with different fat contents would be due to cost differences.

\footnotetext{
${ }^{1}$ Carman's results are consistent with those obtained by other studies of milk transmission processes, including Kinnucan and Forker (1987) and Frigon, Doyan, and Romain (1999).
} 
Actual retail milk prices may differ from the behavior predicted by the competitive model for various reasons. Milk processors may be exercising market power. However, significant vertical market relationships and lack of a wholesale price series restricts analysis of price behavior within the marketing channel. Retailers may also have significant market power as a result of (1) high concentration in local markets, (2) spatial dimensions of retail markets that provide a measure of pricing power to the store located closest to the consumer, (3) less than perfect consumer information and high consumer search costs, and (4) product differentiation among various food retailers in a given market.

A source of pricing power that has not been examined in prior studies of milk pricing is retailers' opportunity to exploit the differential demands among consumers for different fluid milk products. Milk is a horizontally differentiated product at the consumer level. For example, some consumers choose to purchase skim milk because they do not want to consume butterfat. Thus, for constant prices, this consumer prefers skim milk (S) to whole milk (W), two percent butterfat milk $(\mathrm{T})$, or one percent butterfat milk $(\mathrm{O})$. The highest quality milk in terms of component values, whole milk, is not the product uniformly preferred by all consumers. Thus, retailers with market power may be able to exploit horizontal differentiation present in consumers' demand for milk.

Previous studies of supermarket milk pricing have typically relied on a single analytical approach. These approaches have included: (1) graphing farm and retail prices over time and comparing price movements between geographic markets (e.g., Cotterill and Brundage, 2001); (2) statistical analysis of the relationship between farm and retail price changes with hypothesis tests for specific pricing behavior (e.g., Kinnucan and Forker, 1987; Carman, 1998; Cotterill and Dhar, 2003) and (3) econometric modeling of the reaction of milk prices to institutional changes 
or marketing programs (e.g., Cotterill and Franklin, 2001; Bailey, 2003;). This study uses a combination of methods to analyze retail milk pricing in major retail markets in California and neighboring states, including graphical and descriptive analysis and formal econometric modeling with statistical hypothesis tests. Our conclusions regarding competition are based on a preponderance of evidence rather than on the results of a single analytical approach.

\subsection{Graphical Analysis and Descriptive Statistics}

Following Cotterill and Brundage (2001), one can use a graphical approach to examine farm and retail price movements through time in fluid milk markets. The graphical presentation can be supplemented with descriptive statistics, including price correlations. A simple analysis of the correlation between changes in monthly retail milk price provides a measure of the ability of supermarkets to separately vary prices and margins for individual fluid milk products. The variability (and lack of correlation) of milk price changes between markets in California for a given milk product is an indication of the exercise of pricing power in one or more of the markets.

\subsection{Horizontal Differentiation among fluid milk types}

One can derive expected retail price relationships for fluid milk products with different fat contents under perfect competition. Departures from these price relationships provide evidence of the exercise of market power by retailers. To model consumer demand for milk, assume that each consumer will purchase at most one unit of milk per time period. Let $\mathrm{V}_{\mathrm{i}}, \mathrm{i}=\mathrm{W}, \mathrm{T}, \mathrm{O}, \mathrm{S}$ denote a consumer's valuation of milk type $i$, and let $\mathrm{V}^{*}$ denote a reservation utility or outside option, e.g., the utility net of price from consuming an alternative beverage. The consumer maximizes utility by choosing beverage purchases according to the following rule:

$$
\operatorname{Max}\left\{\mathrm{V}_{\mathrm{W}}-\mathrm{P}_{\mathrm{W}, \mathrm{R}}, \mathrm{V}_{\mathrm{T}}-\mathrm{P}_{\mathrm{T}, \mathrm{R}}, \mathrm{V}_{\mathrm{O}}-\mathrm{P}_{\mathrm{O}, \mathrm{R}}, \mathrm{V}_{\mathrm{S}}-\mathrm{P}_{\mathrm{S}, \mathrm{R}}, \mathrm{V}^{*}\right\} \text {, }
$$


i.e., the consumer purchases the product that yields the highest valuation net of price. Because of horizontal differentiation, the rankings of the $\mathrm{V}_{\mathrm{i}}$ differ among consumers.

From a retailer's perspective, this is a relatively standard problem in second-degree price discrimination. The retailer wants to set the prices for $\mathrm{W}, \mathrm{T}, \mathrm{O}$, and $\mathrm{S}$ milk to capture as much of the consumer's surplus as possible. However, the retailer is constrained by the consumer's willingness to switch to a milk type he values less or to the outside option if the retail price is too high for his preferred type.

Milk production and marketing in most of the U.S. is under the control of federal milk marketing orders. California, however, has its own state legislation for milk production, and milk marketing is conducted under rules similar to the federal regulations, but with some important differences. California's standards for fat in whole milk and nonfat solids (SNF) in reduced fat milk products are higher than the federal standards applicable in all other states-table 1.

The content of both milk fat and SNF in raw milk tends to vary seasonally. For example, from April 1999 through April 2003, milk fat in California varied from a monthly average of 3.52 percent to 3.85 percent, while SNF varied from 8.67 to 8.85 percent. Both milk fat and SNF tend to be at seasonal highs in December and January and at seasonal lows during June and July. California milk processors must add SNF throughout the year to meet the standards for $2 \%, 1 \%$ and skim milk, while processors in other states are only concerned with removing milk fat to meet federal standards. Some whole milk may also require fortification if, in its natural state, it contains less than the $8.7 \%$ NFS required. The monthly California Dairy Information Bulletin reports minimum prices for the three major fluid milk components based on the minimum farm price. Using the California standards shown in table 1, a monthly minimum price at the farm 
level can be calculated for each of the four fluid milk products using the component prices. The Northern California average minimum farm prices per gallon for the April 1999 through April 2003 period were as follows: whole milk, $\$ 1.2246$; two-percent milk, $\$ 1.1432$; one-percent milk, $\$ 1.0935$; and skim milk, $\$ 0.8368$. Note that cost differences are primarily due to ingredient costs since all four products must be formulated to meet minimum standards.

Table 1. California and Federal standards for fat and nonfat solids in fluid milk.

\begin{tabular}{|l|c|c|c|c|}
\hline Milk Component & Whole & Two Percent & One Percent & Skim \\
\hline & \multicolumn{3}{|c|}{-------- minimum percent -------- } \\
\hline Fat - California & 3.5 & 2.0 & 1.0 & $0.25^{*}$ \\
\hline Fat - Federal & 3.25 & 2.0 & 1.0 & $0.50^{*}$ \\
\hline SNF - California & 8.6 & 10.0 & 11.0 & 9.0 \\
\hline SNF - Federal & 8.25 & 8.25 & 8.25 & 8.25 \\
\hline
\end{tabular}

* Maximum percentage fat content.

In states other than California, fluid milk processing involves removing milk fat to meet the standards for each of the fluid milk products. Since fat is the most valuable milk component and processing costs per gallon should be relatively constant regardless of fat content, one would expect the net cost of fluid milk products to decrease from whole milk to $2 \%$ milk to $1 \%$ milk and be the lowest for skim milk. Thus, there is a clear ranking in terms of costs of production among $\mathrm{W}, \mathrm{T}, \mathrm{O}$, and $\mathrm{S}$. Removing the butterfat generates a valuable by-product that reduces the costs of T, O, and S milk. The value of this byproduct can be modeled as a negative marginal cost. Denote by-product value as $\mathrm{B}_{\mathrm{i}}, \mathrm{i}=\mathrm{T}, \mathrm{O}, \mathrm{S}$. Then we can write marginal cost $(\mathrm{MC})$ of production functions for each type of fluid milk:

$$
\begin{aligned}
& \mathrm{MC}_{\mathrm{W}}=\mathrm{P}_{\mathrm{F}}+\left(\mathrm{C}_{\mathrm{W}}+\mathrm{C}_{\mathrm{R}}\right)+\mathrm{F}_{\mathrm{W}} \\
& \mathrm{MC}_{\mathrm{T}}=\mathrm{P}_{\mathrm{F}}+\left(\mathrm{C}_{\mathrm{W}}+\mathrm{C}_{\mathrm{R}}\right)+\left(\mathrm{F}_{\mathrm{T}}-\mathrm{B}_{\mathrm{T}}\right) \\
& \mathrm{MC}_{\mathrm{O}}=\mathrm{P}_{\mathrm{F}}+\left(\mathrm{C}_{\mathrm{W}}+\mathrm{C}_{\mathrm{R}}\right)+\left(\mathrm{F}_{\mathrm{O}}-\mathrm{B}_{\mathrm{O}}\right) \\
& \mathrm{MC}_{\mathrm{S}}=\mathrm{P}_{\mathrm{F}}+\left(\mathrm{C}_{\mathrm{W}}+\mathrm{C}_{\mathrm{R}}\right)+\left(\mathrm{F}_{\mathrm{S}}-\mathrm{B}_{\mathrm{S}}\right),
\end{aligned}
$$


where $P_{F}$ is the farm price, $C_{W}$ is per-unit processing cost, $C_{R}$ is per-unit retailing cost, $F_{i}$ is the per-unit cost of fortification, and $B_{i}$ is the per-unit byproduct value. Equations (2) - (5) assume a fixed proportions relationship between the volume of raw milk input and the volume of milk sold at retail. They also assume that retailing costs are constant per-unit and constant across milk types (i.e., a retailer's cost should be unaffected by whether the gallon of milk is whole or skim). Processing costs are also assumed to be constant per unit and across product forms. Milk components are separated and then combined to meet the standards for each product form, so each milk type undergoes the same processing procedure.

In all cases the costs for fortification with NFS are dominated by the value of the butterfat removed. Thus, under perfect competition in pricing by both processors and retailers, the retail price relationship, $\mathrm{P}_{\mathrm{i}, \mathrm{R}}$, among the milk types is the following in both California and neighboring western states:

$$
\begin{aligned}
& \mathrm{P}_{\mathrm{W}, \mathrm{R}}-\mathrm{P}_{\mathrm{T}, \mathrm{R}}=\mathrm{B}_{\mathrm{T}}+\left(\mathrm{F}_{\mathrm{W}}-\mathrm{F}_{\mathrm{T}}\right)>0 \\
& \mathrm{P}_{\mathrm{T}, \mathrm{R}}-\mathrm{P}_{\mathrm{O}, \mathrm{R}}=\left(\mathrm{B}_{\mathrm{O}}-\mathrm{B}_{\mathrm{T}}\right)+\left(\mathrm{F}_{\mathrm{T}}-\mathrm{F}_{\mathrm{O}}\right)>0 \\
& \mathrm{P}_{\mathrm{O}, \mathrm{R}}-\mathrm{P}_{\mathrm{S}, \mathrm{R}}=\left(\mathrm{B}_{\mathrm{S}}-\mathrm{B}_{\mathrm{O}}\right)+\left(\mathrm{F}_{\mathrm{O}}-\mathrm{F}_{\mathrm{S}}\right)>0,
\end{aligned}
$$

i.e., under perfect competition:

$\mathrm{P}_{\mathrm{W}, \mathrm{R}}>\mathrm{P}_{\mathrm{T}, \mathrm{R}}>\mathrm{P}_{\mathrm{O}, \mathrm{R}}>\mathrm{P}_{\mathrm{S}, \mathrm{R}}$

In other words, even though milk is a horizontally differentiated product from consumers' perspectives, from a cost-of-production perspective milk is a vertically differentiated product and pricing under perfect competition is based solely on marginal cost. Whole milk is most expensive to produce because it contains more valuable ingredients than $\mathrm{T}, \mathrm{O}$, or $\mathrm{S}$ milk. Departures from the competitive price ranking in (9) constitute evidence of pricing power on the part of retailers. 


\subsection{Transmission of Farm Price Changes}

Analysis of the transmission of milk price changes from the farm to the retail level provides another approach to measure the exercise of market power. Kinnucan and Forker (1987), Carman (1998), and Frigon, Doyon and Romain (1999), using versions of Houck's (1977) model, and each found asymmetric retail price changes in response to farm price changes, with the speed of retail price changes being faster for farm price increases than for farm price decreases. With the Houck model, changes in the retail price (PR) are linked to increases (PFU) and decreases (PFD) in the farm level price (PF) as follows:

$$
\mathrm{PR}_{\mathrm{t}}=\mathrm{a}_{0} \mathrm{t}+\mathrm{a}_{1} \mathrm{PFU}_{\mathrm{t}}+\mathrm{a}_{2} \mathrm{PFD}_{\mathrm{t}}+\mathrm{a}_{3} \mathrm{C}_{\mathrm{t}}+\mathrm{e}_{\mathrm{t}}
$$

where

$$
\begin{aligned}
& P R_{t}=P_{t}-P_{0} \\
& P F U_{t}=\sum_{t=1}^{T}\left(P F_{t}-P F_{t-1}\right) \text {, if } P F_{t}>P F_{t-1}, \text { and zero otherwise } \\
& P F D_{t}=\sum_{t=1}^{T}\left(P F_{t}-P F_{t-1}\right) \text {, if } P F_{t}<P F_{t-1} \text {, and zero otherwise } \\
& C_{t}=\text { an index of marketing costs. }
\end{aligned}
$$

Thus, $\mathrm{PR}_{\mathrm{t}}$ is the change in retail price at period $\mathrm{t}\left(\mathrm{P}_{\mathrm{t}}\right)$ from its initial value at period $0\left(\mathrm{P}_{0}\right)$. PFU is the sum of all month-to-month increases in the farm price from period 0 to period $t$, and PFD is the sum of all month-to-month decreases in the farm level price from period 0 to period t. As noted by Houck, if the constant $\mathrm{a}_{0}$ is not zero, it appears in (10) as a trend coefficient. The estimated coefficients in (10) can be tested to determine if retail price movements in response to farm price changes are symmetric or asymmetric. The estimated coefficients also provide information on pricing methods used by retailers in a given market area. 
If farm and retail prices move together, then both $\mathrm{a}_{1}$ and $\mathrm{a}_{2}$ will be positive. If the retail price response to changes in the farm price for milk are symmetric for both price increases and decreases, then $a_{1}=a_{2}$. The $t$-statistic is used to test the null hypothesis that retail price movements are symmetric versus the alternative hypothesis that they are asymmetric $\left(a_{1}>a_{2}\right.$ or $\left.a_{1}<a_{2}\right)$. The magnitude of the $a_{1}$ and $a_{2}$ can provide information on retail and wholesale (processor) pricing methods. For example, if retailers and wholesalers use a fixed percentage markup, the two coefficients will be greater than one; if they use a constant dollar markup (consistent with perfect competition and constant marginal costs), the two coefficients will be equal to one; and a combination percentage and constant markup will also yield coefficients greater than one. If retailers and wholesalers follow a practice of stabilizing prices to consumers, then the two coefficients will be positive but less than one.

Failure to reject the hypothesis that $\mathrm{a}_{1}=\mathrm{a}_{2}=1.0$ is a finding consistent with competitive pricing behavior, while rejection of the hypotheses that the coefficients are not equal each other or to 1.0 is evidence of the exercise of market power, given the assumption of constant marginal costs for processing and retailing. In fact, given these assumptions failure to reject the null hypothesis that $\mathrm{a}_{1}=\mathrm{a}_{2}=0.5$ is a finding consistent with monopoly pricing under the additional assumption that demand facing the retailer is linear, i.e., exactly one half of a price change at the farm level is transmitted to retail $\left(a_{1}=a_{2}=0.5\right)$ in this monopoly setting, whereas the price change is transmitted fully under perfect competition. ${ }^{2}$

\section{EMPIRICAL RESULTS}

In this section we show through descriptive statistics, rankings of retail prices by milk product, and estimated price response functions that there is significant evidence of imperfect competition

\footnotetext{
${ }^{2}$ Mathematically, this result is due to marginal revenue having twice the slope of the linear demand curve.
} 
in pricing fluid milk in most of the markets analyzed. However, pricing behavior and marketing margins vary by city and by type of milk product.

\subsection{Descriptive Statistics}

Figures 1 and 2 depict average farm prices and average retail prices by milk type for San Francisco and Seattle from April 1999 through April 2003. Using similar graphs for farm and retail whole milk prices for an earlier period, Cotterill and Brundage (2001) concluded that San Francisco retail milk pricing may be competitive and that severe competition problems exist in Seattle. However, the addition of prices for reduced fat and skim milk suggests that supermarkets are exercising market power in their fluid milk pricing practices in both markets. While there is a rather consistent relationship between the farm price and the retail price for whole milk in San Francisco, the lack of consistent retail pricing relationships between products with different fat contents suggests a departure from perfectly competitive pricing. The relationship between the farm price and the retail price for whole milk in the Seattle market continues to indicate a lack of competition. Retail prices sometimes increased and sometimes decreased when farm prices increased. Two of the three largest retail price decreases for whole milk in Seattle occurred when farm prices were increasing. Graphs for the other California and neighboring markets (not shown due to space considerations) also have price movements that are consistent with the exercise of market power by supermarkets in each of the markets.

Average farm and retail prices for the 49-month period from April 1999 through April 2003 are provided in table 2 . The level and pattern of farm milk prices is very similar for the nine markets. Thus, most of the differences in retail level milk prices by fat content are due to variations in farm to retail milk marketing margins. Seattle had the highest average margins and retail prices for whole and skim milk, while Denver had the highest retail prices for two-percent 
milk, but Seattle had the highest average margins. San Francisco had the highest margins and retail prices for one-percent milk. At the other end of the pricing spectrum, Phoenix had the lowest average retail prices for whole and two-percent milk and was tied with Salt Lake City for lowest average prices for one percent and with Sacramento for lowest average prices for skim milk. Phoenix, with the second highest average farm prices for milk, had the lowest average farm-retail margins for all four products.

Figure 1. San Francisco Milk Prices: Farm and Retail by Fat Content, April 1999 to April 2003.

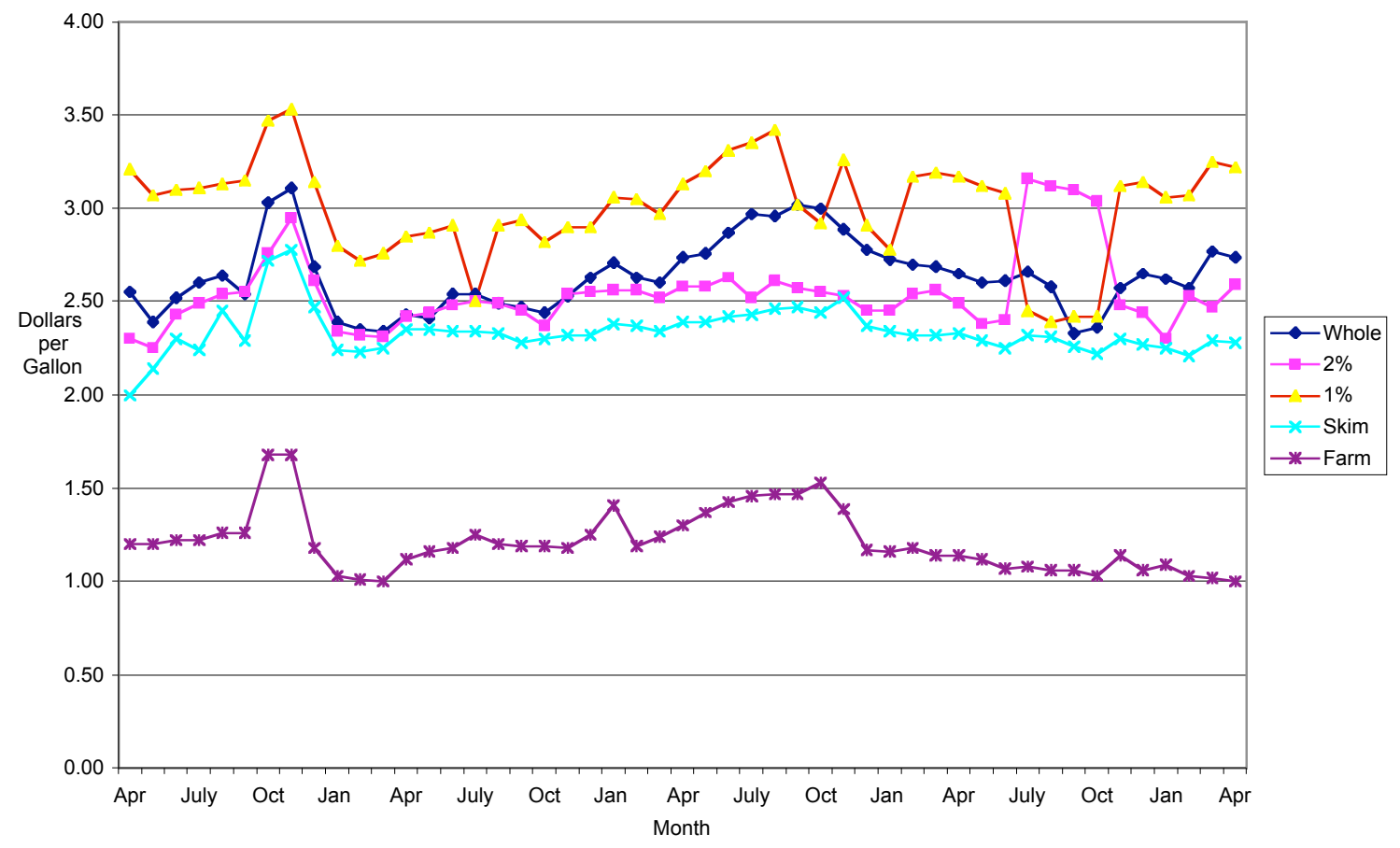


Figure 2. Seattle Milk Prices: Farm and Retail by Fat Content, April 1999 to April 2003.

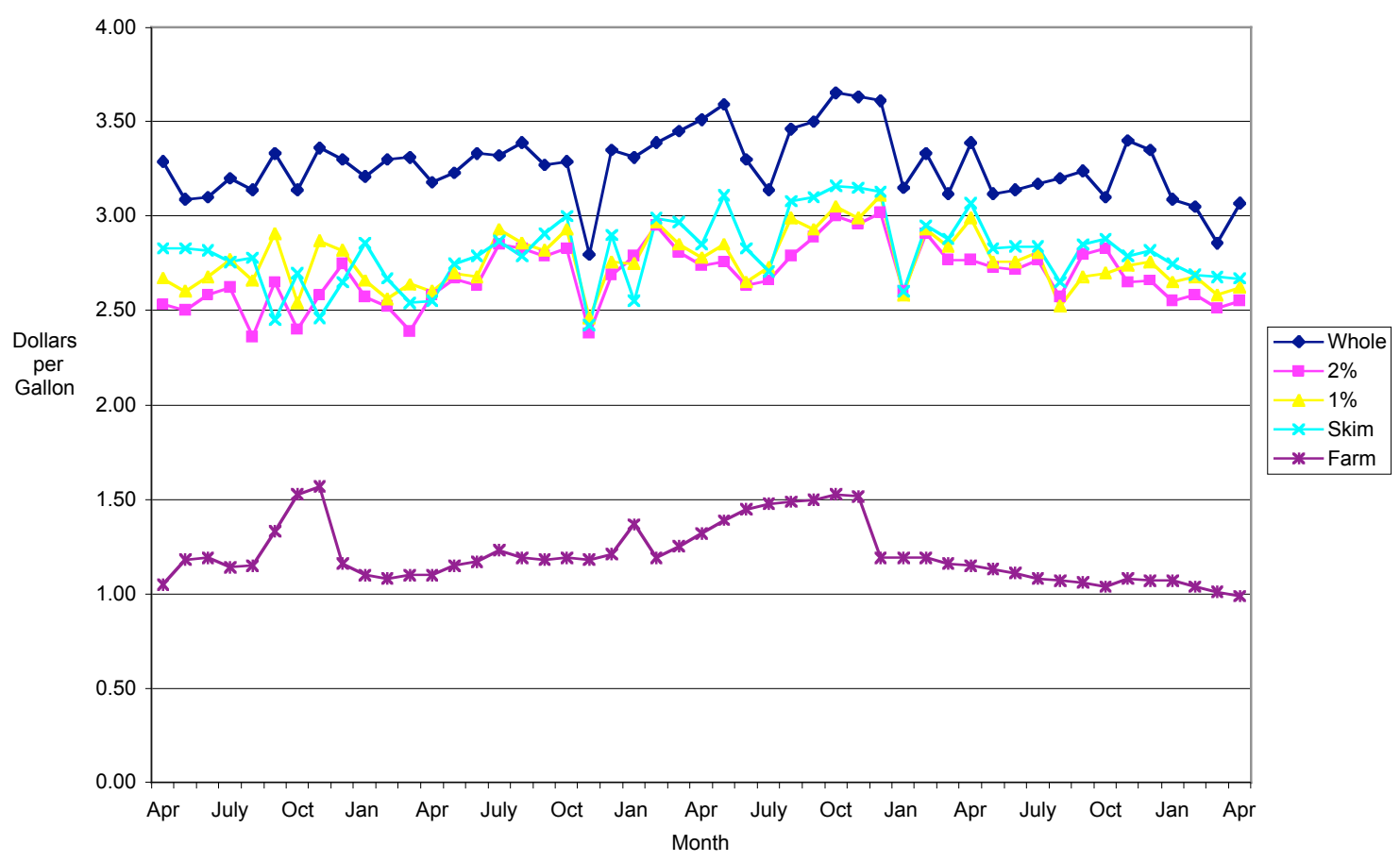

Table 2. Average farm and retail milk prices by market and fat content, April 1999 to April 2003.

\begin{tabular}{|c|c|c|c|c|c|}
\hline \multirow{3}{*}{ Market } & Average & \multicolumn{4}{|c|}{ Average Retail Prices } \\
\hline & Farm Price & Whole & Two Percent & One Percent & Skim \\
\hline & \multicolumn{5}{|c|}{ 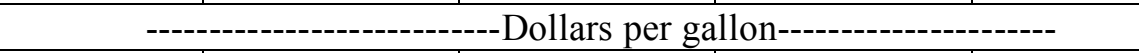 } \\
\hline Sacramento & 1.21 & 2.67 & 2.56 & 2.72 & 2.30 \\
\hline San Francisco & 1.21 & 2.64 & 2.55 & 3.01 & 2.34 \\
\hline Los Angeles & 1.24 & 2.84 & 2.70 & 2.82 & 2.78 \\
\hline San Diego & 1.24 & 2.77 & 2.65 & 2.76 & 2.77 \\
\hline Seattle & 1.21 & 3.27 & 2.69 & 2.76 & 2.81 \\
\hline Portland & 1.21 & 2.82 & 2.43 & 2.39 & 2.37 \\
\hline Salt Lake City & 1.21 & 2.60 & 2.32 & 2.22 & 2.42 \\
\hline Denver & 1.27 & 2.86 & 2.73 & 2.66 & 2.66 \\
\hline Phoenix & 1.25 & 2.34 & 2.21 & 2.22 & 2.30 \\
\hline
\end{tabular}

In addition to studying the relative price levels, comparing patterns in price changes over time can also reveal evidence about market behavior. In California changes in the minimum farm prices are the same across the state due to regulation. Of course, changes over time in 
processing and retailing costs may not be the same across the entire state, but they should be due to the same basic economic forces and, thus, similar. Therefore, under competitive pricing retail price changes for each milk type in the four California cities should be highly correlated. Following Stigler and Sherwin (1985), we computed correlations of first differences in the logarithms of prices (essentially correlations of the percent price changes) for each milk type in each of the four major California markets. The results, reported in table 3 , indicate a high degree of pricing independence across cities for each milk type. The highest correlations are generally for whole milk, ranging from 0.93 (Sacramento and San Francisco) to 0.68 (San Diego and San Francisco). Correlations of price changes for two-percent milk are much lower on average. San Diego price changes exhibit almost no correlation with changes in two-percent prices in the other cities. Correlations of changes in one-percent milk prices range from 0.81 (Los Angeles and San Diego) to 0.38 (Los Angeles and San Francisco). For skim milk, the correlations in the price changes range from 0.82 (Los Angeles and San Diego) to 0.18 (Sacramento and San Francisco). Correlations of the log price changes for the five nonCalifornia cities (not reported due to space considerations) are even lower, and often are negative, even though the correlation of changes in the logs of the farm prices for these five markets are all in excess of 0.99 . These low correlations in the price changes all speak to considerable pricing independence for retailers that is not consistent with competitive pricing. ${ }^{3}$

\footnotetext{
${ }^{3}$ It is worth emphasizing that because these prices are citywide averages, idiosyncratic price changes, e.g., due to sales, within individual stores or chains should have limited impacts on the overall averages, reinforcing the observation that the correlations of the price changes should be high if price changes were primarily in response to cost changes.
} 
Table 3. Correlation matrix for logarithm of milk price changes by fat content for California markets

\begin{tabular}{|c|c|c|c|c|c|c|c|c|c|c|c|c|c|c|c|c|c|}
\hline & \multicolumn{4}{|c|}{ Whole Milk } & \multicolumn{4}{|c|}{ Two Percent } & \multicolumn{4}{|c|}{ One Percent } & \multicolumn{4}{|c|}{ Skim } \\
\hline & & Sac & $\mathrm{SF}$ & LA & SD & Sac & SF & LA & SD & Sac & SF & LA & SD & Sac & SF & LA & SD \\
\hline \multirow[t]{4}{*}{ Whole } & Sac & 1.0 & & & & & & & & & & & & & & & \\
\hline & SF & .93 & 1.0 & & & & & & & & & & & & & & \\
\hline & LA & .78 & .72 & 1.0 & & & & & & & & & & & & & \\
\hline & SD & .73 & .68 & .92 & 1.0 & & & & & & & & & & & & \\
\hline \multirow[t]{4}{*}{ Two } & $\mathrm{Sac}$ & & & & & 1.0 & & & & & & & & & & & \\
\hline & SF & & & & & .80 & 1.0 & & & & & & & & & & \\
\hline & LA & & & & & .63 & .32 & 1.0 & & & & & & & & & \\
\hline & SD & & & & & .09 & .03 & .07 & 1.0 & & & & & & & & \\
\hline \multirow[t]{4}{*}{ One } & $\mathrm{Sac}$ & & & & & & & & & 1.0 & & & & & & & \\
\hline & SF & & & & & & & & & .66 & 1.0 & & & & & & \\
\hline & LA & & & & & & & & & .67 & .38 & 1.0 & & & & & \\
\hline & SD & & & & & & & & & .69 & .49 & .81 & 1.0 & & & & \\
\hline \multirow[t]{4}{*}{ Skim } & $\mathrm{Sac}$ & & & & & & & & & & & & & 1.0 & & & \\
\hline & SF & & & & & & & & & & & & & .46 & 1.0 & & \\
\hline & LA & & & & & & & & & & & & & .18 & .40 & 1.0 & \\
\hline & SD & & & & & & & & & & & & & .24 & .51 & .82 & 1.0 \\
\hline
\end{tabular}

\subsection{Price Rankings by Product}

As noted, milk is a vertically differentiated product from a cost-of-production perspective, but not from a consumer demand perspective. Whole milk is most expensive to produce because it contains more valuable ingredients than two percent, one percent or skim milk, and therefore under competitive pricing we expect to observe the pricing condition in (9): $\mathrm{P}_{\mathrm{W}, \mathrm{R}}>\mathrm{P}_{\mathrm{T}, \mathrm{R}}>\mathrm{P}_{\mathrm{O}, \mathrm{R}}>$ $\mathrm{P}_{\mathrm{S}, \mathrm{R}}$. Based on the average retail prices in table 2, the expected price relationship is observed on average for only one market, Portland.

A measure of average price rankings by market for the 49 month period was constructed as follows: average retail prices were ranked for each month with the highest price receiving a rank of one and the lowest price receiving a rank of four. If two prices were equal, each received an average of the higher and lower ranking. Then averages of the rankings over the 49 months were calculated for each market. The results are in table 4. The rank values under perfect competition are whole milk $=1.0$, two-percent milk $=2.0$, one-percent milk $=3.0$, and skim milk $=4.0$. Note 
that only three entries in table 4 conformed fully with price expectations based on cost for all months during the observation period; whole milk in Seattle and skim milk in Sacramento and San Francisco. Overall, the expected ordering of prices for all four products holds on average only for Portland and, even there, the rank values indicate that two percent, one percent and skim milk were often not in the expected order. One-percent milk on average was the most expensive milk type in Sacramento and San Francisco. Both one-percent and skim milk on average were more expensive than two-percent milk in Los Angeles and San Diego. Skim milk tended to be more expensive than one-percent and two-percent milk in Salt Lake City and Phoenix. Based on the data summarized in table 4, we conclude that supermarkets are using second-degree price discrimination to exploit consumers' heterogeneous preferences for milk, and, thus, that the pricing behavior is not consistent with perfect competition.

Table 4. Average monthly retail price ranking of milk products by market, April 1999 through April 2003.

\begin{tabular}{|l|c|c|c|c|}
\hline \multirow{2}{*}{ Market } & \multicolumn{5}{|c|}{ Average Rank of Retail Price by Product $(1.0=$ highest price $)$} \\
\cline { 2 - 5 } & Whole & \multicolumn{1}{|c|}{ Two Percent } & \multicolumn{1}{c|}{ One Percent } & Skim \\
\hline Sacramento & 1.86 & 2.80 & 1.35 & 4.00 \\
\hline San Francisco & 2.06 & 2.76 & 1.18 & 4.00 \\
\hline Los Angeles & 1.88 & 3.49 & 1.97 & 2.66 \\
\hline San Diego & 2.14 & 3.70 & 1.99 & 2.16 \\
\hline Seattle & 1.00 & 3.77 & 2.88 & 2.36 \\
\hline Portland & 1.02 & 2.40 & 3.28 & 3.31 \\
\hline Salt Lake City & 1.05 & 2.93 & 3.76 & 2.27 \\
\hline Denver & 1.04 & 2.38 & 3.38 & 3.20 \\
\hline Phoenix & 1.90 & 3.15 & 2.90 & 2.05 \\
\hline
\end{tabular}

\subsection{Transmission of Farm Price Changes}

Farm-level milk prices in California and neighboring states are set by formulas based on costs of production and prices of dairy products. Under a perfectly competitive pricing system, these 
price changes will be transmitted to the retail level, with retail prices moving in the same direction as farm price changes with a very short lag based on product in the distribution system.

Transmission of milk price changes from the farm to the retail level was analyzed using equation (10). The farm price data to accompany the 49 months of retail price data were obtained from the California Department of Food and Agriculture (CDFA). The index of marketing costs $\left(C_{t}\right)$ in (10) is the Economic Research Service, USDA total marketing cost index published in monthly issues of Agricultural Outlook.

Kinnucan and Forker (1987) found evidence of lagged price adjustments extending up to three months for fluid milk in New York. Carman (1998), using California data on whole milk prices, found only a one-month lag between farm price decreases and total retail price decreases for each market area and no lag for farm price increases. Our procedure was to estimate (10) for each market using an Almon distributed lag model, with an initial lag of three months specified. The number of months lagged was then reduced to include only the lagged coefficients that were significantly different than zero. The estimated coefficients for the marketing cost variable were not significantly different than zero in any of the markets, and, thus, this variable was deleted from the analysis. Significant serial correlation was evident in all of the equations estimated, and a Cochrane-Orcutt iterative type procedure was used to re-estimate each of the equations. The following is a presentation and discussion of the estimated price response functions for each of the retail markets in the study.

Sacramento: Estimation results are shown in table 5. The model explains from 31 (skim milk) to 94 percent (whole milk) of the variation in retail milk prices. Several significant lags for retail price adjustments were found, although none exceeded one month. Retail prices for whole milk took one month to adjust to farm price increases. Retail prices for whole, one percent, and 
skim milk also required one month to adjust to farm price decreases. Each of the estimated retail price response coefficients for farm price increases $\left(\sum \mathrm{a}_{1}\right)$ was larger than the coefficients for farm price decreases $\left(\Sigma \mathrm{a}_{2}\right)$, and three of the four differences were significant, indicating that Sacramento retailers increased prices more than they decreased prices for an equal farm price change for whole, two percent and skim milk. Hypotheses tests that the estimated coefficients for farm price increases and decreases were equal to one were not rejected for five of the eight coefficients. The coefficient for whole milk increases was significantly greater than one and both coefficients for two-percent milk were significantly less than one. The null hypothesis that each coefficient for two-percent milk was equal to 0.50 was not rejected.

Table 5. Price parameter estimates for retail milk price response to farm price changes for Sacramento

\begin{tabular}{|c|l|c|c|c|c|c|}
\hline Fat Content & \multirow{2}{*}{$\begin{array}{c}\text { Months } \\
\text { Lagged }\end{array}$} & \multicolumn{2}{|c|}{ Parameter Estimates (Standard Errors) } & \multicolumn{2}{c|}{ Statistics } \\
\cline { 3 - 6 } & & \multicolumn{2}{|c}{$\mathrm{a}_{0}$} & \multicolumn{2}{|c|}{$\Sigma \mathrm{a}_{1}$} & \multicolumn{2}{c|}{$\Sigma \mathrm{a}_{2}$} & $\mathrm{R}^{2}$ & D.W. \\
\hline \multirow{2}{*}{ Whole } & up $=1$ & -0.154 & 1.222 & 0.937 & .94 & 1.86 \\
& down $=1$ & $(0.0837)^{*}$ & $(0.104)$ & $(0.0881)$ & & \\
\hline \multirow{2}{*}{ Two Percent } & up $=0$ & -0.075 & 0.719 & 0.520 & .75 & 2.10 \\
& down $=0$ & $(0.0591)$ & $(0.110)$ & $(0.0985)$ & & \\
\hline One Percent & up $=0$ & -0.173 & 0.983 & 0.835 & .83 & 1.70 \\
& down $=1$ & $(0.100)$ & $(0.111)$ & $(0.105)$ & & \\
\hline Skim & up $=0$ & -0.053 & 1.157 & 0.968 & .31 & 2.02 \\
& down $=1$ & $(0.0862)$ & $(0.250)$ & $(0.223)$ & & \\
\hline
\end{tabular}

The price ranking by product for Sacramento had one-percent milk priced highest during 35 of 49 months (71 percent), whole milk highest for 10 months, and two-percent milk highest for four months. While whole milk was usually priced second highest and two-percent milk third highest, these positions sometimes changed. Evidence of market power being exercised in pricing milk for the Sacramento market includes larger retail price coefficients for farm price increases than for farm price decreases, retail price coefficients for two-percent milk that are 
most consistent with monopoly pricing, and one-percent milk being priced higher than whole and two-percent milk.

San Francisco: Estimation results are shown in table 6. The model explains from 47 (two-percent milk) to 87 percent (whole milk) of the variation in retail milk prices. In general, retail prices in San Francisco adjusted rather quickly to farm price changes. Retail prices for two-percent milk took one month to adjust to farm price increases. Retail prices for whole, one percent, and skim milk also required one month to adjust to farm price decreases. In all other cases, retail prices adjusted contemporaneously with the farm price change. While the estimated retail price adjustment coefficients for farm price increases are larger than for farm price decreases, only the difference for whole milk was significant. Hypotheses tests that the estimated coefficients for farm price increases and decreases were equal to one were not rejected for five of the eight coefficients. The coefficient for two-percent price decreases to farm price decreases was significantly less than one, as were both coefficients for skim milk price decreases. The monopoly null hypothesis that each coefficient was equal to 0.50 was not rejected for retail price increases and decreases for two percent and one-percent milk. The hypothesis tests for skim milk indicate that the coefficients are less than one but greater than 0.50 .

The price ranking by product for San Francisco showed one-percent milk priced highest during 42 of 49 months. While whole milk was usually priced second highest (40 months) and two-percent milk third highest, these positions sometimes changed. Evidence of market power being exercised in pricing milk for the San Francisco market includes retail price coefficients for two percent and skim milk that were significantly less than one (and consistent with monopoly pricing), and one-percent milk being priced higher than whole and two-percent milk. 
Table 6. Price parameter estimates for retail milk price response to farm price changes for San Francisco

\begin{tabular}{|c|c|c|c|c|c|c|}
\hline \multirow[t]{2}{*}{ Fat Content } & \multirow{2}{*}{$\begin{array}{l}\text { Months } \\
\text { Lagged }\end{array}$} & \multicolumn{3}{|c|}{ Parameter Estimates (Standard Errors) } & \multicolumn{2}{|c|}{ Statistics } \\
\hline & & $a_{0}$ & $\Sigma \mathrm{a}_{1}$ & $\Sigma \mathrm{a}_{2}$ & $\mathrm{R}^{2}$ & D.W. \\
\hline Whole & $\begin{array}{c}\text { up }=0 \\
\text { down }=1\end{array}$ & $\begin{array}{c}-0.119 \\
(0.0577)^{*}\end{array}$ & $\begin{array}{c}1.148 \\
(0.1139) \\
\end{array}$ & $\begin{array}{c}0.943 \\
(0.1030) \\
\end{array}$ & .87 & 1.79 \\
\hline Two Percent & $\begin{array}{c}\text { up }=1 \\
\text { down }=0\end{array}$ & $\begin{array}{c}0.105 \\
(0.1311)\end{array}$ & $\begin{array}{c}0.645 \\
(0.2600)\end{array}$ & $\begin{array}{c}0.487 \\
(0.2273)\end{array}$ & .47 & 1.72 \\
\hline One Percent & $\begin{array}{c}\text { up }=0 \\
\text { down }=1\end{array}$ & $\begin{array}{c}-0.260 \\
(0.1389) \\
\end{array}$ & $\begin{array}{c}0.950 \\
(0.2836) \\
\end{array}$ & $\begin{array}{c}0.906 \\
(0.2560) \\
\end{array}$ & .54 & 1.85 \\
\hline Skim & $\begin{array}{c}\text { up }=0 \\
\text { down }=1\end{array}$ & $\begin{array}{c}0.294 \\
(0.0268)\end{array}$ & $\begin{array}{c}0.679 \\
(0.0708)\end{array}$ & $\begin{array}{c}0.645 \\
(0.0633)\end{array}$ & .77 & 1.95 \\
\hline
\end{tabular}

Los Angeles: Estimation results are shown in table 7. The model explains from 75 (skim milk) to 97 percent (whole milk) of the variation in retail milk prices. Retail price adjustments lagged farm price decreases by one month for one-percent milk, by two months for whole and skim milk, and by three months for two-percent milk. Retail price increases lagged farm price increases by one month for whole and two-percent milk, but there were no significant lags in adjustment to price increases for skim and one-percent milk. Note that three of the retail coefficients for farm price decreases were larger than the coefficients for farm price increases. However, the null hypothesis that retail price response was equal for farm price increases and farm price decreases was not rejected for any of the four products. Hypotheses tests that the estimated coefficients for farm price increases and decreases are equal to one were not rejected for seven of the eight coefficients, skim milk price increases representing the only exception. The monopoly null hypothesis that each coefficient was equal to 0.50 was not rejected for retail price increases for one-percent and skim milk and for retail price decreases for skim milk. 
Table 7. Price parameter estimates for retail milk price response to farm price changes for Los Angeles

\begin{tabular}{|c|c|c|c|c|c|c|}
\hline \multirow[t]{2}{*}{ Fat Content } & \multirow{2}{*}{$\begin{array}{l}\text { Months } \\
\text { Lagged }\end{array}$} & \multicolumn{3}{|c|}{ Parameter Estimates (Standard Errors) } & \multicolumn{2}{|c|}{ Statistics } \\
\hline & & $\mathrm{a}_{0}$ & $\Sigma \mathrm{a}_{1}$ & $\Sigma \mathrm{a}_{2}$ & $\mathrm{R}^{2}$ & D.W. \\
\hline Whole & $\begin{array}{c}\text { up }=1 \\
\text { down }=2\end{array}$ & $\begin{array}{c}-0.373 \\
(0.0685)^{*}\end{array}$ & $\begin{array}{c}1.151 \\
(0.0869) \\
\end{array}$ & $\begin{array}{c}1.055 \\
(0.0778) \\
\end{array}$ & .97 & 2.03 \\
\hline Two Percent & $\begin{array}{c}\text { up }=1 \\
\text { down }=3\end{array}$ & $\begin{array}{c}-0.322 \\
(0.0504)\end{array}$ & $\begin{array}{c}0.994 \\
(0.0951) \\
\end{array}$ & $\begin{array}{c}1.025 \\
(0.0857) \\
\end{array}$ & .95 & 1.81 \\
\hline One Percent & $\begin{array}{c}\text { up }=0 \\
\text { down }=1\end{array}$ & $\begin{array}{c}-0.108 \\
(0.0698)\end{array}$ & $\begin{array}{c}0.752 \\
(0.1272) \\
\end{array}$ & $\begin{array}{c}0.897 \\
(0.1150) \\
\end{array}$ & .88 & 2.03 \\
\hline Skim & $\begin{array}{c}\text { up }=0 \\
\text { down }=2\end{array}$ & $\begin{array}{c}-0.216 \\
(0.1101)\end{array}$ & $\begin{array}{c}0.596 \\
(0.1577)\end{array}$ & $\begin{array}{c}0.754 \\
(0.1480)\end{array}$ & .75 & 1.72 \\
\hline
\end{tabular}

Whole milk had the highest price in Los Angeles during 21 of 49 months, one-percent milk had the highest price for 17 months, and skim milk had the highest price for 11 months. The monthly rankings by product changed frequently and were never completely consistent with the cost ranking. Evidence of market power being exercised in pricing milk for the Los Angeles market includes retail price adjustments to farm price decreases taking longer than adjustments to farm price increases and monthly rankings of prices that were inconsistent with product costs.

San Diego: Estimation results are shown in table 8. The model explains from 72 (twopercent milk) to 94 percent (whole milk) of the variation in retail milk prices. Retail price adjustments to farm price decreases were in general much slower than adjustments to farm price increases in San Diego. The lag in adjustment to farm price decreases ranged from one month for skim milk to three months for one-percent and whole milk. Retail price increases lagged farm price increases by one month for whole milk, but there was no significant lag in adjustment for the other milk types. The hypothesis that the coefficients for retail price adjustments to increases and decreases in farm prices were equal was not rejected for any of the four products. Hypothesis tests that the estimated coefficients for farm price increases and decreases were equal to one were not rejected for whole and one-percent milk and were rejected for two percent and skim milk. The monopoly null hypothesis that each coefficient was equal to 0.50 was not 
rejected for retail price increases for two-percent and skim milk and for retail price decreases for skim milk.

Table 8. Price parameter estimates for retail milk price response to farm price changes for San Diego

\begin{tabular}{|c|c|c|c|c|c|c|}
\hline \multirow[t]{2}{*}{ Fat Content } & \multirow{2}{*}{$\begin{array}{l}\text { Months } \\
\text { Lagged }\end{array}$} & \multicolumn{3}{|c|}{ Parameter Estimates (Standard Errors) } & \multicolumn{2}{|c|}{ Statistics } \\
\hline & & $\mathrm{a}_{0}$ & $\Sigma \mathrm{a}_{1}$ & $\Sigma \mathrm{a}_{2}$ & $\mathrm{R}^{2}$ & D.W. \\
\hline Whole & $\begin{array}{c}\text { up }=1 \\
\text { down }=3\end{array}$ & $\begin{array}{c}-0.285 \\
(0.0620)^{*}\end{array}$ & $\begin{array}{c}1.091 \\
(0.1170)\end{array}$ & $\begin{array}{c}1.095 \\
(0.1050)\end{array}$ & .94 & 2.20 \\
\hline Two Percent & $\begin{array}{c}\text { up }=0 \\
\text { down }=2\end{array}$ & $\begin{array}{c}-0.210 \\
(0.0484)\end{array}$ & $\begin{array}{c}0.691 \\
(0.1198) \\
\end{array}$ & $\begin{array}{c}0.747 \\
(0.1060) \\
\end{array}$ & .72 & 2.08 \\
\hline One Percent & $\begin{array}{c}\text { up }=0 \\
\text { down }=3\end{array}$ & $\begin{array}{c}-0.152 \\
(0.0436)\end{array}$ & $\begin{array}{c}0.906 \\
(0.1029)\end{array}$ & $\begin{array}{c}0.958 \\
(0.0903)\end{array}$ & .86 & 2.10 \\
\hline Skim & $\begin{array}{c}\text { up }=0 \\
\text { down }=1\end{array}$ & $\begin{array}{c}-0.134 \\
(0.0830)\end{array}$ & $\begin{array}{c}0.559 \\
(0.1118)\end{array}$ & $\begin{array}{c}0.577 \\
(0.1030)\end{array}$ & .78 & 1.89 \\
\hline
\end{tabular}

Whole milk had the highest price in San Diego during 16 of 49 months, two-percent milk was highest for one month, one-percent milk was highest for 14 months, and skim milk was highest for 17 months. Skim milk was priced lowest in only two months, despite being the lowcost product. The monthly rankings by product changed frequently and were never completely consistent with the cost ranking. Evidence of market power being exercised in pricing milk for the San Diego market includes retail price adjustments to farm price decreases taking longer than adjustments to farm price increases, retail price coefficients for two percent and skim milk that were significantly less than one (and consistent with monopoly pricing), and monthly rankings of prices that were inconsistent with product costs.

Seattle: Estimation results are contained in table 9. The explanatory power of the equations is relatively low, with $\mathrm{R}^{2}$ statistics ranging from a low of 0.27 (skim milk) to a high of 0.40 (twopercent milk). There were significant one-month lag for retail price adjustments to farm price decreases for all four milk products and to farm price increases for two percent, one percent and skim milk. There was no lag for whole milk retail price adjustments to farm price increases. 
The hypothesis that the coefficients for retail price adjustments to increases and decreases in farm prices were equal was not rejected for any of the four products. The hypotheses that the estimated coefficients were equal to 1.0 was rejected in all cases except for price increases for whole milk. The monopoly null hypothesis that each coefficient was equal to 0.50 was not rejected for retail price increases or decreases for any of the four products.

Table 9. Price parameter estimates for retail milk price response to farm price changes for Seattle

\begin{tabular}{|c|c|c|c|c|c|c|}
\hline \multirow[t]{2}{*}{ Fat Content } & \multirow{2}{*}{$\begin{array}{l}\text { Months } \\
\text { Lagged }\end{array}$} & \multicolumn{3}{|c|}{ Parameter Estimates (Standard Errors) } & \multicolumn{2}{|c|}{ Statistics } \\
\hline & & $\mathrm{a}_{0}$ & $\Sigma \mathrm{a}_{1}$ & $\Sigma \mathrm{a}_{2}$ & $\mathrm{R}^{2}$ & D.W. \\
\hline Whole & $\begin{array}{c}\text { up }=0 \\
\text { down }=1\end{array}$ & $\begin{array}{c}-0.216 \\
(0.0640)^{*}\end{array}$ & $\begin{array}{c}0.720 \\
(0.1535)\end{array}$ & $\begin{array}{c}0.639 \\
(0.1400)\end{array}$ & .35 & 1.65 \\
\hline Two Percent & $\begin{array}{c}\text { up }=1 \\
\text { down }=1\end{array}$ & $\begin{array}{c}-0.074 \\
(0.0604) \\
\end{array}$ & $\begin{array}{c}0.568 \\
(0.1410) \\
\end{array}$ & $\begin{array}{c}0.392 \\
(0.1390) \\
\end{array}$ & .40 & 1.43 \\
\hline One Percent & $\begin{array}{c}\text { up }=1 \\
\text { down }=1\end{array}$ & $\begin{array}{c}-0.059 \\
(0.0577) \\
\end{array}$ & $\begin{array}{c}0.593 \\
(0.1350) \\
\end{array}$ & $\begin{array}{c}0.522 \\
(0.1320) \\
\end{array}$ & .37 & 2.10 \\
\hline Skim & $\begin{array}{c}\text { up }=1 \\
\text { down }=1\end{array}$ & $\begin{array}{c}-0.194 \\
(0.0766)\end{array}$ & $\begin{array}{c}0.597 \\
(0.1790)\end{array}$ & $\begin{array}{c}0.464 \\
(0.1760)\end{array}$ & .27 & 1.88 \\
\hline
\end{tabular}

Among the nine markets, Seattle had the highest average prices and margins for whole milk and for skim milk and the highest average margins for two-percent milk during the sample period (table 2). In fact, Seattle's average margin for whole milk of $\$ 2.06$ per gallon was $\$ .45$ per gallon higher than Portland's, which had the second highest margin, and \$0.97 per gallon higher than Phoenix, which had the lowest margin for whole milk. The price ranking by product for Seattle had whole milk priced highest every month, as expected. Skim milk had the secondhighest pricing for 38 months and, while the two-percent milk price typically ranked third or fourth. Monthly rankings for two percent, one percent and skim milk changed frequently and were as expected only one week out of the 49 weeks observed. Evidence of market power being exercised in pricing milk for the Seattle market includes its high margins relative to other WestCoast cities, the relatively low explanatory power of the price transmission equations, the fact 
that none the eight price transmission coefficients were significantly different from the monopoly value of 0.5 , and monthly rankings of prices for two percent, one percent and skim milk that were inconsistent with product costs.

Portland: The estimated price response functions for Portland (table 10) have very low explanatory power, with $\mathrm{R}^{2}$ statistics ranging from less than one percent (skim milk) to a high of 0.16 (two-percent milk). The most striking feature of the estimated coefficients for retail price response to farm price changes is that all are less than 0.30 , and none are significantly different from zero. The obvious conclusion is that retail prices in the Portland market were not responding to farm price changes during the study period. Observed changes in retail prices for each of the milk products were mainly due to retailer decisions based on factors other than changes in product costs.

Table 10. Price parameter estimates for retail milk price response to farm price changes for Portland

\begin{tabular}{|c|c|c|c|c|c|c|}
\hline \multirow[t]{2}{*}{ Fat Content } & \multirow{2}{*}{$\begin{array}{l}\text { Months } \\
\text { Lagged }\end{array}$} & \multicolumn{3}{|c|}{ Parameter Estimates (Standard Errors) } & \multicolumn{2}{|c|}{ Statistics } \\
\hline & & $\mathrm{a}_{0}$ & $\Sigma \mathrm{a}_{1}$ & $\Sigma \mathrm{a}_{2}$ & $\mathrm{R}^{2}$ & D.W \\
\hline Whole & $\begin{array}{c}\text { up }=0 \\
\text { down }=0\end{array}$ & $\begin{array}{c}-0.109 \\
(0.0782)^{*}\end{array}$ & $\begin{array}{c}0.199 \\
(0.1982) \\
\end{array}$ & $\begin{array}{c}0.095 \\
(0.1857) \\
\end{array}$ & .05 & 1.89 \\
\hline Two Percent & $\begin{array}{c}\text { up }=0 \\
\text { down }=0\end{array}$ & $\begin{array}{c}0.153 \\
(0.0838)\end{array}$ & $\begin{array}{c}0.200 \\
(0.2001)\end{array}$ & $\begin{array}{c}0.299 \\
(0.1872)\end{array}$ & .16 & 2.07 \\
\hline One Percent & $\begin{array}{c}\text { up }=0 \\
\text { down }=0\end{array}$ & $\begin{array}{c}0.164 \\
(0.0906) \\
\end{array}$ & $\begin{array}{c}0.246 \\
(0.2097) \\
\end{array}$ & $\begin{array}{c}0.282 \\
(0.1960) \\
\end{array}$ & .14 & 2.04 \\
\hline Skim & $\begin{array}{c}\text { up }=0 \\
\text { down }=0\end{array}$ & $\begin{array}{c}0.015 \\
(0.0692)\end{array}$ & $\begin{array}{c}0.030 \\
(0.1755)\end{array}$ & $\begin{array}{c}0.037 \\
(0.1644)\end{array}$ & .001 & 1.83 \\
\hline
\end{tabular}

The overall rankings of Portland milk prices are in the order expected (table 4) and whole milk is priced highest for 48 of the 49 months. The rankings for the other three products vary by month, with skim milk ranking in second and third place as many times as it appears in fourth place. Evidence of market power being exercised in pricing milk for the Portland market includes the low explanatory power of the price transmission equations, the fact that none of the 
price transmission coefficients are significantly greater than zero, and monthly rankings of prices for two percent, one percent and skim milk that are inconsistent with product costs.

Salt Lake City: The variables included in the equations for Salt Lake City explain from 66 (two-percent milk) to 79 percent (whole milk) of the variation in retail milk prices (table 11). Retail milk prices in Salt Lake City responded much slower to farm price increases than to increases at the farm level. The lag in adjustment to price decreases was three months for months for whole, one-percent and skim milk. The only lag in adjustment to farm price increases was one month for whole milk. A comparison of the coefficients for retail price adjustments to farm price increases and decreases shows that the coefficients for farm price decreases are larger for all four products. The difference is significant for two percent and onepercent milk. Hypotheses tests that the estimated coefficients for farm price increases and decreases were equal to one was not rejected for whole milk but were rejected for both coefficients for two percent, one percent and skim milk. The monopoly null hypothesis that each coefficient was equal to 0.50 was not rejected for any of the eight coefficients.

Table 11. Price parameter estimates for retail milk price response to farm price changes for Salt Lake City

\begin{tabular}{|c|c|c|c|c|c|c|}
\hline \multirow[t]{2}{*}{ Fat Content } & \multirow{2}{*}{$\begin{array}{l}\text { Months } \\
\text { Lagged }\end{array}$} & \multicolumn{3}{|c|}{ Parameter Estimates (Standard Errors) } & \multicolumn{2}{|c|}{ Statistics } \\
\hline & & $\mathrm{a}_{0}$ & $\Sigma \mathrm{a}_{1}$ & $\Sigma \mathrm{a}_{2}$ & $\mathrm{R}^{2}$ & D.W. \\
\hline Whole & $\begin{array}{c}\text { up }=1 \\
\text { down }=3\end{array}$ & $\begin{array}{c}0.003 \\
(0.1164)^{*}\end{array}$ & $\begin{array}{c}0.555 \\
(0.2250)\end{array}$ & $\begin{array}{c}0.826 \\
(0.2070)\end{array}$ & .79 & 1.91 \\
\hline Two Percent & $\begin{array}{c}\text { up }=0 \\
\text { down }=0\end{array}$ & $\begin{array}{c}0.125 \\
(0.0600) \\
\end{array}$ & $\begin{array}{c}0.435 \\
(0.1422) \\
\end{array}$ & $\begin{array}{c}0.697 \\
(0.1330) \\
\end{array}$ & .66 & 2.03 \\
\hline One Percent & $\begin{array}{c}\text { up }=0 \\
\text { down }=3\end{array}$ & $\begin{array}{c}-0.062 \\
(0.0728)\end{array}$ & $\begin{array}{c}0.388 \\
(0.1459) \\
\end{array}$ & $\begin{array}{c}0.576 \\
(0.1310) \\
\end{array}$ & .73 & 1.89 \\
\hline Skim & $\begin{array}{c}\text { up }=0 \\
\text { down }=3\end{array}$ & $\begin{array}{c}0.175 \\
(0.0939) \\
\end{array}$ & $\begin{array}{c}0.432 \\
(0.1760) \\
\end{array}$ & $\begin{array}{c}0.536 \\
(0.1610) \\
\end{array}$ & .72 & 1.70 \\
\hline
\end{tabular}

Whole milk prices ranked the highest for 46 out of 49 months in Salt Lake City but skim milk prices were the lowest only three out of 49 months. Skim milk prices ranked second 
highest for 37 months, with the rankings among two-percent, one-percent and skim milk changing during the other months. Evidence of market power being exercised in pricing milk for the Salt Lake City market includes the significant three month lags for retail prices for whole, one-percent and skim milk to respond to farm price decreases, rejection of the hypothesis that the price transmission coefficients for two percent, one percent and skim milk were equal to one (and failure to reject the hypothesis that the coefficients were equal to 0.50 for all four products), and monthly rankings of prices for two-percent, one-percent and skim milk that were inconsistent with product costs.

Denver: The explanatory power of the Denver market equations are relatively low, with $\mathrm{R}^{2}$ statistics ranging from a low of 0.37 (skim milk) to a high of 0.59 for whole milk (table 12). There were significant lags of one or two months for retail prices to respond to farm price increases farm price increases for all four products, and for retail price decreases to farm price decreases for two-percent and skim milk. Denver was the only market among the nine studied to show a generally faster response to farm price decreases than to farm price increases. The hypothesis tests provided consistent results for all four products. The hypothesis that retail price adjustments are equal for farm price increases and farm price decreases was not rejected for any of the four products. However, the hypothesis that coefficients were equal to one was rejected for all four products in favor of the alternative that the coefficients were less than one. The monopoly null hypothesis that each of the eight coefficients was equal to 0.50 was not rejected. 
Table 12. Price parameter estimates for retail milk price response to farm price changes for Denver

\begin{tabular}{|c|c|c|c|c|c|c|}
\hline \multirow[t]{2}{*}{ Fat Content } & \multirow{2}{*}{$\begin{array}{l}\text { Months } \\
\text { Lagged }\end{array}$} & \multicolumn{3}{|c|}{ Parameter Estimates (Standard Errors) } & \multicolumn{2}{|c|}{ Statistics } \\
\hline & & $a_{0}$ & $\Sigma \mathrm{a}_{1}$ & $\Sigma \mathrm{a}_{2}$ & $\mathrm{R}^{2}$ & D.W. \\
\hline Whole & $\begin{array}{c}\text { up }=1 \\
\text { down }=0\end{array}$ & $\begin{array}{c}-0.250 \\
(0.1777)^{*}\end{array}$ & $\begin{array}{c}0.428 \\
(0.2600)\end{array}$ & $\begin{array}{c}0.402 \\
(0.2179)\end{array}$ & .59 & 2.17 \\
\hline Two Percent & $\begin{array}{c}\text { up }=1 \\
\text { down }=1\end{array}$ & $\begin{array}{c}-0.242 \\
(0.1097) \\
\end{array}$ & $\begin{array}{c}0.556 \\
(0.2200) \\
\end{array}$ & $\begin{array}{c}0.553 \\
(0.2030) \\
\end{array}$ & .47 & 2.24 \\
\hline One Percent & $\begin{array}{c}\text { up }=1 \\
\text { down }=0\end{array}$ & $\begin{array}{c}-0.192 \\
(0.1432)\end{array}$ & $\begin{array}{c}0.465 \\
(0.2630)\end{array}$ & $\begin{array}{c}0.400 \\
(0.2350)\end{array}$ & .38 & 2.33 \\
\hline Skim & $\begin{array}{c}\text { up }=2 \\
\text { down }=2\end{array}$ & $\begin{array}{c}-0.163 \\
(0.1068)\end{array}$ & $\begin{array}{c}0.501 \\
(0.2540)\end{array}$ & $\begin{array}{c}0.409 \\
(0.2430)\end{array}$ & .37 & 2.21 \\
\hline
\end{tabular}

Whole milk was usually priced highest in Denver (47 out of 49 months), and two-percent milk was usually in second place (34 out of 49 months). One-percent milk was priced lowest in 26 months, and skim milk was priced lowest in 20 months. The expected price ranking of whole, two percent, one percent and skim milk was observed during 16 months, the highest of any of the markets. Evidence of market power being exercised in pricing milk for the Denver market is rather mixed. Farm price increases did not transmit more slowly than farm price decreases, but transmission was only partial in all instances and not inconsistent with monopoly behavior. Moreover, monthly rankings of prices for two percent, one percent and skim milk were not consistent with product costs.

Phoenix: The variables included in the equations for Phoenix explain from 16 (skim milk) to 68 percent (whole milk) of the variation in retail milk prices (table 13). There were significant lags of one to three months in retail price adjustments to farm price decreases for whole, two percent and one-percent milk. The only significant lag for a farm price increase was a one month lag for one-percent milk. While the estimated coefficients for retail price adjustments to farm price decreases are slightly larger than the coefficients for farm price increases, the hypothesis that retail price adjustments are equal for farm price increases and farm price decreases was not 
rejected for any of the four products. However, the hypothesis that the coefficients were equal to one was rejected for all four products in favor of the alternative that the coefficients were less than one. The monopoly null hypothesis that each of coefficients is equal to 0.50 was not rejected for whole, two-percent, and one-percent milk. Neither of the retail price adjustment coefficients for skim milk was significantly different than zero.

Table 13. Price parameter estimates for retail milk price response to farm price changes for Phoenix

\begin{tabular}{|c|c|c|c|c|c|c|}
\hline \multirow[t]{2}{*}{ Fat Content } & \multirow{2}{*}{$\begin{array}{l}\text { Months } \\
\text { Lagged }\end{array}$} & \multicolumn{3}{|c|}{ Parameter Estimates (Standard Errors) } & \multicolumn{2}{|c|}{ Statistics } \\
\hline & & $\mathrm{a}_{0}$ & $\Sigma \mathrm{a}_{1}$ & $\Sigma \mathrm{a}_{2}$ & $\mathrm{R}^{2}$ & D.W. \\
\hline Whole & $\begin{array}{c}\text { up }=0 \\
\text { down }=1\end{array}$ & $\begin{array}{c}0.202 \\
(0.1480)^{*}\end{array}$ & $\begin{array}{c}0.228 \\
(0.2610) \\
\end{array}$ & $\begin{array}{c}0.475 \\
(0.2370) \\
\end{array}$ & .68 & 2.10 \\
\hline Two Percent & $\begin{array}{c}\text { up }=0 \\
\text { down }=3\end{array}$ & $\begin{array}{c}0.008 \\
(0.1002)\end{array}$ & $\begin{array}{c}0.563 \\
(0.2147)\end{array}$ & $\begin{array}{c}0.590 \\
(0.1920)\end{array}$ & .36 & 1.99 \\
\hline One Percent & $\begin{array}{c}\text { up }=1 \\
\text { down }=3\end{array}$ & $\begin{array}{c}-0.080 \\
(0.1003)\end{array}$ & $\begin{array}{c}0.585 \\
(0.2147) \\
\end{array}$ & $\begin{array}{c}0.633 \\
(0.1920) \\
\end{array}$ & .40 & 2.00 \\
\hline Skim & $\begin{array}{c}\text { up }=0 \\
\text { down }=0\end{array}$ & $\begin{array}{c}0.161 \\
(0.1067)\end{array}$ & $\begin{array}{c}0.045 \\
(0.2437)\end{array}$ & $\begin{array}{c}0.057 \\
(0.2283)\end{array}$ & .16 & 2.22 \\
\hline
\end{tabular}

The ranking of milk prices in Phoenix had each product ranked in each position at least once during the 49 months. Whole milk was priced highest for 26 months and skim milk was priced highest for 14 months. There was only $\$ 0.04$ per gallon difference between average retail prices for whole and skim milk. Each product was also priced lowest during at least one month whole milk for eight months, two-percent milk for 20 months, one-percent milk for 9 months and skim milk for 8 months. A retail price ranking consistent with costs occurred only two out of 49 months. Evidence of market power being exercised in pricing milk for the Phoenix market is mixed. Phoenix had the lowest average prices for whole and two-percent milk and tied for the lowest prices for one percent and skim milk. Phoenix average margins were the lowest for all four products. However, the relatively low explanatory power of the price transmission equations for the two reduced fat and skim milk products, rejection of the hypothesis that the 
retail price transmission coefficients were equal to one for all four products and failure to reject the hypothesis that each coefficient was equal to 0.50 for whole, two percent and one-percent milk, and monthly rankings of prices that were inconsistent with product costs all constitute evidence in support of the exercise of market power.

\section{CONCLUSIONS}

Our analysis reveals significant evidence of the use of market power in pricing fluid milk in each of the nine markets analyzed. Each of the three analytical techniques revealed departures from competitive pricing for one or more products in multiple markets. Analysis of the ranking of retail prices based on product costs found that none of the markets had the consistent ranking (from highest to lowest) for whole milk, two-percent milk, one-percent milk, and skim milk prices predicted by perfect competition. Whole milk prices were always the highest for only market, Seattle, and were usually the highest for three more, Portland, Salt Lake City and Denver. Skim milk prices were always the lowest for only two markets, Sacramento and San Francisco. At the same time, retail skim milk prices were often higher than two percent and onepercent milk prices in Seattle, Salt Lake City and Phoenix. Retail prices for one-percent milk were often highest in Sacramento, San Francisco, and San Diego.

The addition of two-percent, one-percent and skim milk to the analysis of retail price response to farm price changes and retail pricing behavior paints a quite different picture than did previous analyses that considered only whole milk. The price transmission equations for whole milk in the four California markets estimated in this study are similar to those estimated by Carman (1998), where the main departures from competitive pricing appeared to be in the time lags required for retailers to respond to farm price decreases. 
Results of the price transmission analysis differ by area. The four California markets have a number of retail price coefficients for farm price increases and decreases that are consistent with competitive pricing and several that are not. The hypothesis that coefficients are equal to one was rejected for two-percent milk in Sacramento and San Diego and for skim milk in San Francisco, Los Angeles, and San Diego. The monopoly hypothesis that the coefficients are equal to 0.50 was not rejected for two-percent milk in Sacramento and San Francisco, for one-percent milk in San Francisco, and for skim milk in Los Angeles and San Diego. However, in general retail prices responded more quickly to farm price increases than to farm price decreases in the California markets.

Price transmission equations for the five markets outside California provide even stronger evidence of the exercise of market power in milk pricing by supermarkets. None of the estimated price transmission coefficients for Portland was significantly different than zero, indicating that retail prices did not respond to farm price changes. The hypothesis that the coefficients were equal to one was rejected for all four products in Denver and Phoenix and for two-percent, one-percent and skim milk in Seattle and Salt Lake City. The hypothesis that the coefficients were equal to 0.50 was not rejected for any of the four milk products in Seattle, Salt Lake City, and Denver and for whole, two-percent and one-percent milk in Phoenix. The estimated coefficients for skim milk in Phoenix were not significantly different than zero. Thus, for the five markets outside California, only three of 40 estimated coefficients (whole milk price increases in Seattle and Salt Lake City and whole milk price decreases in Salt Lake City) were consistent with perfect competition in pricing.

In closing, a couple of limitations of the study should be emphasized. Although we benefited from being able to analyze prices for each of the four major types of fluid milk, the 
prices we studied were market-wide averages. Further insights could be developed by looking at the behavior of retail chains within each city using scanner data. Second, lack of a wholesale price series comparable to the price series utilized for farm and retail prices made it impossible to analyze processor-retailer interactions and to decompose the farm-retail price spreads into their farm-wholesale and wholesale-retail components. The assumption carried forward in this study was that departures from competition were most likely due to retailers' behavior. This assumption seems reasonable in light of the structure of the dairy industry, the evolving recognition of the role of retailer power in the food chain, ${ }^{4}$ and the considerable heterogeneity in pricing behavior in the individual markets. However, if wholesale price series were available, incorporating the role of processors in the market channel would represent a valuable extension to the present analysis.

\footnotetext{
${ }^{4}$ See Kaufman (2000) for a summary of recent consolidation in grocery retailing, and Sexton, Zhang, and Chalfant (2003) for a summary of prior research on grocery retailer market power.
} 


\section{REFERENCES}

Bailey, K.W. (2003) Impact of the Northeast Interstate Dairy Compact on Consumer Prices for Fluid Milk. Review of Agricultural Economics, Spring, 108-22.

Carman, H.F. (1998). California Milk Marketing Margins. Journal of Food Distribution Research, November, 1-6.

Cotterill, R.W. and Brundage, M.F. (2001). Competition, or the Lack Thereof in Local Fluid Milk Markets: San Francisco, Seattle, Chicago, Miami and Dallas-Fort Worth. University of Connecticut, Food Marketing Policy Center, Issue Paper No. 21.

Cotterill, R.W. and Dhar, T. (2003) Oligopoly Pricing with Differentiated Products: The Boston Fluid Milk Market Channel. University of Connecticut, Food Marketing Policy Center, Research Report Series No. 74.

Cotterill, R.W. and Franklin, A. (2001) The Public Interest and Private Economic Power: A Case Study of the Northeast Dairy Compact. University of Connecticut, Food Marketing Policy Center, Monograph No. 1.

Dairy Marketing Branch, California Agricultural Statistics Service. California Dairy Information Bulletin. Sacramento, California, monthly issues.

Economic Research Service, U.S. Department of Agriculture. Agricultural Outlook.

Washington, D.C., monthly issues.

Frigon, M., Doyon, M. and Romain, R. (1999). Asymmetry in Farm-Retail Price Transmission In the Northeastern Fluid Milk Market. University of Connecticut, Food Marketing Policy Center, Research Report No. 45.

Houck, J.P. (1977). An Approach to Specifying and Estimating Nonreversible Functions. American Journal of Agricultural Economics, 59, 570-572. 
Kaufman, P. (2000). Consolidation in food retailing: prospects for consumers \& grocery suppliers, Agricultural Outlook, August, 18-22.

Kinnucan, H.W. and Forker, O.D. (1987). Asymmetry in Farm-Retail Price Transmission for Major Dairy Products. American Journal of Agricultural Economics, 69, 285-292.

Odabashian, E. (1997a). Got Moo-La? Bay Area Grocers Continue to Gouge Consumers on Milk. Consumers Union of U.S., Inc., West Coast Regional Office, March.

Odabashian, E. (1997b). Got Moo-La? Los Angeles Grocers Continue to Gouge Consumers on Milk. Consumers Union of U.S., Inc., West Coast Regional Office, June.

Sexton, R.J., Zhang, M., and Chalfant, J.C. (2003). Grocery Retailer Behavior in the Procurement and Sale of Perishable Fresh Produce Commodities. U.S. Department of Agriculture, Economic Research Service, Contributors and Cooperators Report No. 2, September. 